\title{
ADSORPTION METHOD PURIFICATION OF ALKYLATES, FROM ADMIXTURES OF ALUMINIUM CHLORIDE, HYDROGEN CHLORIDE AND RESIDUES OF HIGHMOLECULAR HYDROCARBONS
}

Amirov F.A. ${ }^{1}$, Shakhverdiyeva F.M. ${ }^{2}$, Sultanova G.J. ${ }^{3}$ Email: Amirov1134@ scientifictext.ru

\author{
${ }^{l}$ Amirov Fariz Ali oglu - doctor of technical sciences, professor, chief of department; \\ ${ }^{2}$ Shakhverdiyeva Fatima Maqomed qizi - associate professor, \\ DEPARTMENT OF PETROCHEMICAL TECHNOLOGY AND INDUSTRIAL ECOLOGY; \\ ${ }^{3}$ Sultanova Gulnara Jamil qizi - associate professor, \\ DEPARTMENT OF PETROCHEMICAL TECHNOLOGY AND INDUSTRIAL ECOLOGY, \\ FACULTY OF CHEMICAL TECHNOLOGY, \\ AZERBAIJAN STATE UNIVERSITY OF OIL AND TECHNOLOGY, BAKU, REPUBLIC OF AZERBAIJAN
}

\begin{abstract}
: in present work for purification of alkylates, received in the process alkylation of benzene in presence of catalyst aluminium chloride and polluted by admixtures of aluminium chloride and hydrogen chloride the adsorption purification by olid natural sorbents was offered.

It is give a possibility to replace a traditional water-alkaline purification accompanying by formation of the water-alkaline flows, loss of valuable hydrocarbons and compounds of aluminium. The adsorbents, used in the work shown a high dynamical adsorptive ability relatively to admixtures and a high degree use of adsorption capacity of sorbent, being for different sorbents within 0,80-0,89 relatively to aluminium chloride and 0,89-0,93-relatively to hydrogen chloride.
\end{abstract}

Keywords: alkylate, water-alkaline purification, adsorbent, sulface-active substance, regeneration of adsorbent.

\section{АДСОРБЦИОННАЯ ОЧИСТКА АЛКИЛАТОВ ОТ ПРИМЕСЕЙ ХЛОРИСТОГО АЛЮМИНИЯ, ХЛОРИСТОГО ВОДОРОДА И ОСТАТКОВ ВЫСОКОМОЛЕКУЛЯРНЫХ УГЛЕВОДОРОДОВ}

\author{
Амиров Ф.А.' ${ }^{1}$ Шахвердиева Ф.М. ${ }^{2}$, Султанова Г.Дж. ${ }^{3}$ \\ ${ }^{1}$ Амиров Фариз Али огль - доктор технических наук, профессор, заведуюший кафедрой; \\ ${ }^{2}$ Шахвердиева Фатима Магомед кызы - кандидат технических наук, доцент, \\ кафедра технологии органических и высокомолекулярных соединений; \\ ${ }^{3}$ Султанова Гюльнара Дюсамиль кызы - кандидат химических наук, дочент, \\ кафедра нефтехимической технологии и промышленной экологии, \\ химико-технологический факультет. \\ Азербайджанский государственный университет нефти и промышленности, г. Баку, Азербайджсанская Республика
}

\begin{abstract}
Аннотация: в настоящей работе предложено для очистки алкилатов, полученных в процессе алкилирования бензола в присутствии катализатора хлористого алюминия и загрязненных примесями хлористого алюминия $и$ хлористого водорода, использовать адсорбционную очистку твердыми природными сорбентами.

Это дает возможность заменить традиционную водно-щелочную очистку, сопровождающуюся образованием водно-щелочных стоков, потерей ценных углеводородов и соединений алюминия. Используемые в работе адсорбенты показали высокую динамическую адсорбционную способность относительно примесей и высокую степень использования адсорбиионной емкости сорбента, находящуюся для разных сорбентов в пределах 0,80 - 0,89 относительно хлористого алюминия и 0,89 - 0,93 относительно хлористого водорода.
\end{abstract}

Ключевые слова: алкилат, водно-щелочная очистка, адсорбент, поверхностно-активное вещество, регенерация адсорбента.

UDK 66.66.081

A scale production of high alkylbenzenes is explained by their use for production of surface-active substances, in the main for anion-active detergents, synthetical oils, freezing by lon temperature, consistant lubricants.

The alkylbenzene is produced by alkylation of benzene by high olefines.

In reactions alkylation of benzene by high olefines as catalyst the protone and aprotoneacidssulphuric acid, hydrogen fluoride, silicotungsten acid, acid exchange resins, zeolites, boron fluoride, aluminium chloride and also some another compounds are used.

By that alkylation of benzene by high olefines proceeds by consistent-parallel mechanisnm and mono-and polyalkylbenzenes are formed that decrease the process selectivity. The most active catalyst of dealkylation is aluminium chloride that is the reason of big interest to this catalyst.

But the aluminium chloride smaller and smaller is used in world practice because it is the catalyst making worse the ecology of environment.

By existing in the world practice technologscol scheme by production of high alkylbenzenes in presence of $\mathrm{AlCl}_{3}$ purification of alkylate from admixtures of hydrogen chloride is realized by traditional method-water-alkaline processing.

Repeated washing gives a significant volume of polluted waters. By data of the work [1] by production of 1 ton alkylbenzene 10-12 $\mathrm{m}^{3}$ of waste waters is formed. They don't may be directed on biological purification because aluminium hydroxide, containing in waste waters has a disastrous influence on activity of biological sludge [2]. On the other hand a big 
amount of aluminium compounds, being a valuable raw material for many industrial branch and also hydrocarbons are lost with waste lasts. The waste waters by this composition present a big danger for water basins and decrease the economic indices of alkylation process. The shortage of traditional purification is also inevitable corrosion of equipment.

The research, conducted by us are devoted to search of the new nontraditional method purification of alkylate by adsorption with solid adsorbenti allowing to create the highproductive wasteless technology production of high alkylbenzenes. As a solid adsorbents, used for purification of alkylates from containing in it admixtures of aluminium chloride and neavyhighmolecular hydrocarbons (residue) by us the aluminium oxide, mordenite, clinoptylolite, zeolitecontaining ZEOCAR-3 have been researched and before described. The investigations have shown a possibility purification of alkylates by "dry" method by high purification degree. The results of investigations are presented in the tables 1. and 2. The adsorption was conducted in column, filled up by adsorbent. The alnylate was suppling with constant rate over adsorbent. Over appointed interval of time a sample of aluminium chloride and hydrogene chloride was determined. After that as adsorbent was saturating by admixtures, the adsorption column was washing by solvent-benzene for desorption of alkylaromatic hydrocarbons and was carrying at the plant of adsorbent regeneration.

In the table 1 the results adsorption on different sorbents, shown a high dynamical activity (100 gram) by relation to purification of admixtures and high degree use of adsorption capacity being within $0,76-0,82$. Have been presented from literary data it is known that by designing of recuperation plants it is necessary to select a sizes of adsorber by that way its value "a" was no more 0,8 .

The parameters, described in the table 1 have been determined by the following method.

By calculation of the working layer height of adsorbent the known dependence of Maykl Treyblse [5] have been used:

$$
L_{o}=L \frac{\tau_{e q}-\tau_{o v}}{\tau_{e q}-(1-\varphi)\left(\tau_{e q}-\tau_{o v}\right)}
$$

$\mathrm{L}$ - height of adsorbent in column; $\mathrm{L}_{0}$ - height of the working layer of adsorbent;

$\tau_{\text {eq- }}$ time of appearance of eqnilibrium concentration of admixture; $\tau$ - time of overshoot admixture beyond of adsorbent layer; $\varphi$ - coefficient of symmetry, shown the degree non-use of adsorption capacity in working layer.

The use degree of adsorption capacity of sorbent was determined by correlation of adsorption layer height $\mathrm{L}$ and height of the working layer $\mathrm{L}_{0}$ by formula (2)

$$
\alpha=\frac{L-\varphi L_{0}}{L}
$$

\begin{tabular}{|c|c|c|c|c|c|c|c|c|c|c|c|}
\hline \multirow[t]{2}{*}{ 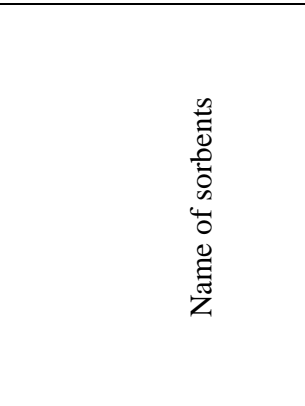 } & 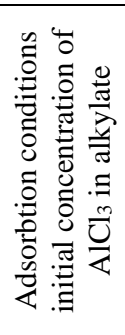 & 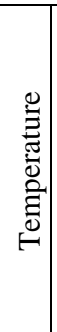 & 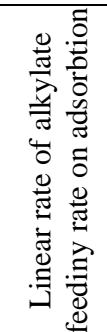 & 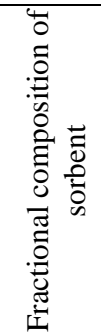 & 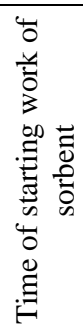 & 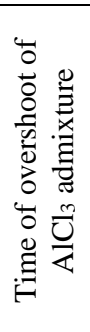 & 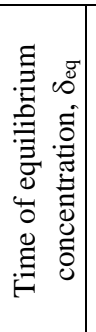 & 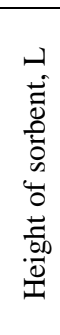 & 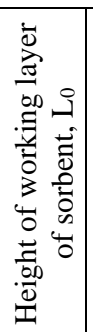 & 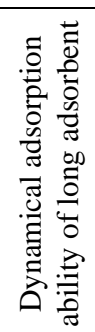 & 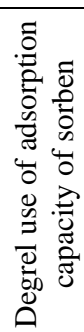 \\
\hline & $\%$ mas & $\begin{array}{l}0 \\
\mathrm{C}\end{array}$ & $\begin{array}{c}\mathrm{sm} / \mathrm{mi} \\
\mathrm{n}\end{array}$ & $\mathrm{mm}$ & $\min$ & $\min$ & $\min$ & $\mathrm{sm}$ & $\mathrm{sm}$ & $\mathrm{g}$ & \\
\hline $\begin{array}{c}\text { Clinoptilolite } \mathrm{H}^{+} \text {by } \\
0,1 \% \mathrm{HCl} \\
\end{array}$ & 0,42 & $\begin{array}{l}2 \\
0 \\
\end{array}$ & 0,06 & $\begin{array}{c}0,1- \\
0,2 \\
\end{array}$ & 0,00 & 300 & 430 & 14 & 4,65 & 15,4 & 0,80 \\
\hline $\begin{array}{c}\text { Aluminium oxide } \\
\text { after thermoprocessing }\end{array}$ & 0,767 & $\begin{array}{l}2 \\
0\end{array}$ & 0,60 & $0,1-0$ & 0,00 & 150 & 200 & 10 & 2,70 & 13,5 & 0,81 \\
\hline $\begin{array}{l}\text { Aluminium oxide } \\
\text { after thermoprocessing }\end{array}$ & 0,61 & $\begin{array}{l}2 \\
0\end{array}$ & 0,0 & $\begin{array}{l}0,1- \\
0,2\end{array}$ & 0,00 & 190 & 250 & 10 & 258 & 13,67 & 0,82 \\
\hline $\begin{array}{l}\text { Zeokar-3 (syntketical } \\
\text { zeolite containing } \\
\text { sobent) }\end{array}$ & 0,61 & $\begin{array}{l}2 \\
0\end{array}$ & 0,06 & $\begin{array}{l}0,1- \\
0,2\end{array}$ & 0,00 & 270 & 330 & 14 & 2,24 & 13,9 & 0,89 \\
\hline
\end{tabular}

Table 1. Experimental and rated characteristics of dynamic sorbtion of $\mathrm{AlCl}_{3}$ from alkylate by solid sorbents

\begin{tabular}{|c|c|c|c|c|c|c|c|c|c|c|c|}
\hline \multirow[b]{2}{*}{ 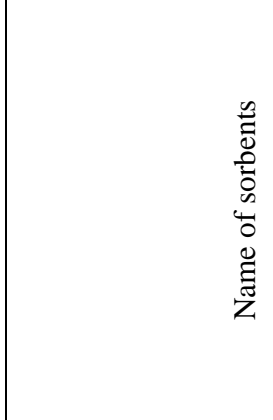 } & $\begin{array}{c}\text { Conditions } \\
\text { of the } \\
\text { process }\end{array}$ & \multirow[b]{2}{*}{ 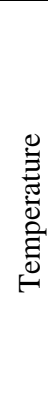 } & \multirow{2}{*}{ 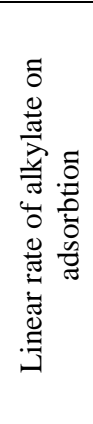 } & \multirow{2}{*}{ 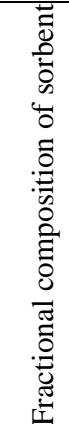 } & \multirow{2}{*}{ 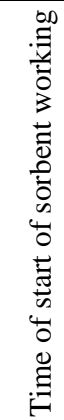 } & \multirow{2}{*}{ 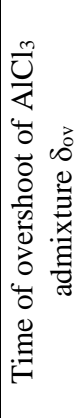 } & \multirow[b]{2}{*}{ 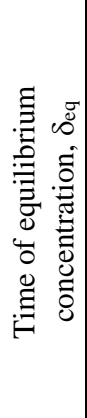 } & \multirow{2}{*}{ 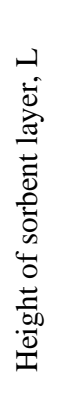 } & \multirow{2}{*}{ 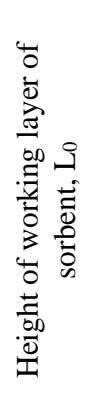 } & \multirow{2}{*}{ 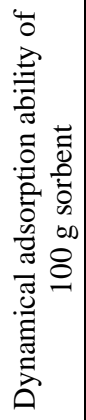 } & \multirow{2}{*}{ 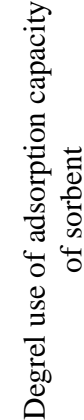 } \\
\hline & $\begin{array}{c}\text { Concentratio } \\
n \text { of } \mathrm{HCl}\end{array}$ & & & & & & & & & & \\
\hline
\end{tabular}

Table 2. Experimental and rated characteristics of dynamic sorpion of $\mathrm{HCl}$ from alkylate by solid sorbents 


\begin{tabular}{|c|c|c|c|c|c|c|c|c|c|c|c|}
\hline & moll & $\begin{array}{c}0 \\
\mathrm{C}\end{array}$ & $\begin{array}{c}\mathrm{sm} / \mathrm{mi} \\
\mathrm{n}\end{array}$ & $\mathrm{mm}$ & $\mathrm{min}$ & $\mathrm{min}$ & $\mathrm{min}$ & $\mathrm{sm}$ & $\mathrm{sm}$ & $\mathrm{g}$ & \\
\hline $\begin{array}{c}\text { Clinoptilolite } \mathrm{H}^{+} \\
\text {by 0,1\% HCl }\end{array}$ & 0,119 & $\begin{array}{c}2 \\
0\end{array}$ & 0,06 & $\begin{array}{c}0,1- \\
0,2\end{array}$ & 0,00 & 95 & 110 & 14 & 2,05 & 3,5 & 0,89 \\
\hline $\begin{array}{c}\text { Aluminium oxide } \\
\text { after thermoprocessing }\end{array}$ & 0,157 & 2 & 0,06 & $\begin{array}{c}0,1- \\
0,2\end{array}$ & 0,00 & 190 & 218 & 10 & 1,33 & 12,8 & 0,90 \\
\hline $\begin{array}{c}\text { Zeokar-3(syntketical } \\
\text { zeolite containing } \\
\text { sobent) }\end{array}$ & 0,10 & 2 & 0,06 & $\begin{array}{c}0,1- \\
0,2\end{array}$ & 0,00 & 90 & 210 & 17 & 1,66 & 2,28 & 0,93 \\
\hline
\end{tabular}

The dynamical adsorption ability of 100 gram of adsorbent was determined proceeding from rate feed of alkylate, the initial concentration of admixture and time of admixture overshoot.

In the table 2 the results adsorption of hydrogen chloride admixture in alkylate on different sorbent are shown. As it is shown from results, presented in table 2, the investigated samples of adsorbents are on active to relation of hydrogen chloride admixture. About that a high degree use of adsorption capacity of sorbents being within 0,89 - 0,93 is testified.

The regeneration of saturated by admixtures adsorbent is conducted by air-vapor mixture (air-distillated water) by $200 \mathrm{C}$ temperature. By that the hydrolysis of adsorbed on sorbent surface of aluminiumchloride is takes place. Subsequent heating of saturated sorbent under stream of humid air up to $450-600^{\circ} \mathrm{C}$ lead to oxidation regeneration, which consist in dehydration of.

Aluminium chloride hydrolysis and burning of highmoleculr hydrocarons residues. Formed by dehydration aluminium oxide is stayed on surface of adsorbent.

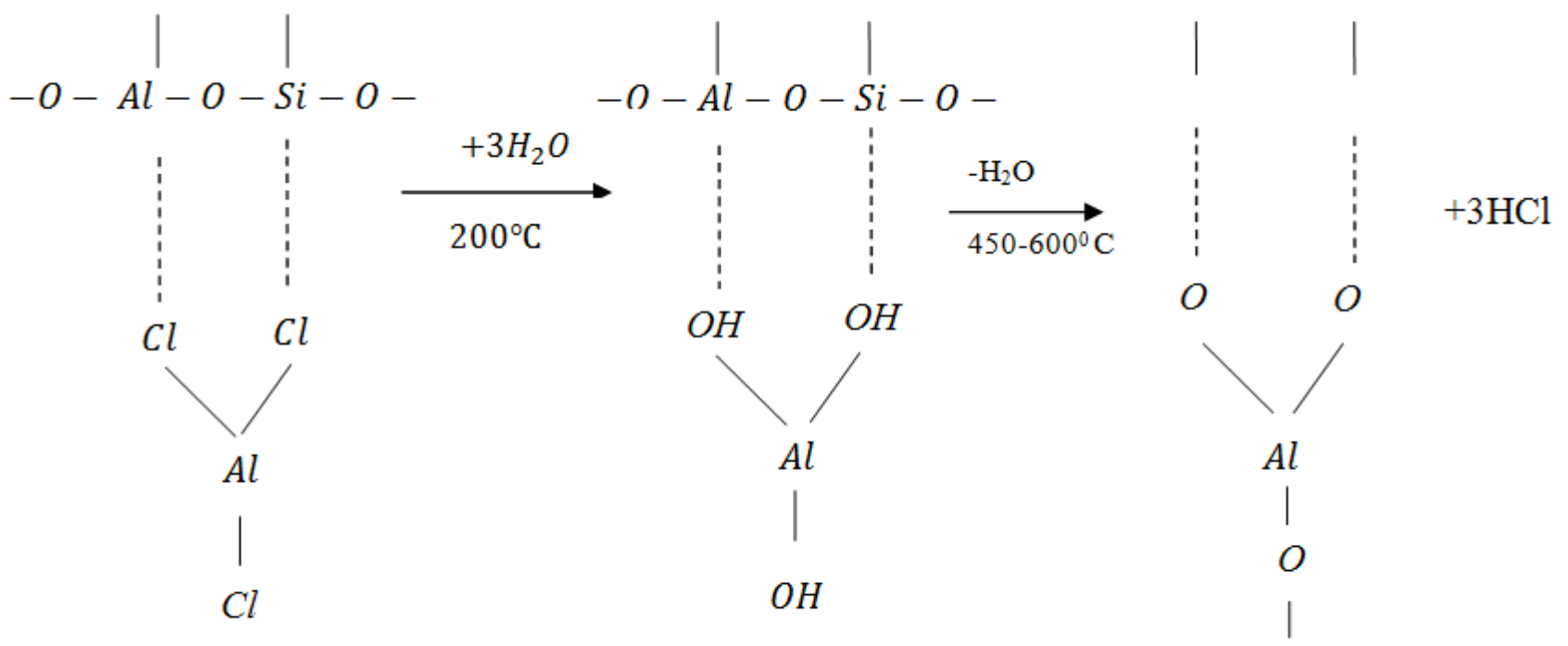

$2 \mathrm{AlCl}_{3}+3 \mathrm{H}_{2} \mathrm{O} \longrightarrow \mathrm{Al}_{2} \mathrm{O}_{3}+6 \mathrm{HC}$

Conclusions:

1. The technology adsorption purification of alkylates, received in reaction alkylation of benzene by high alkenes in presence of catalyst Aluminium chloride, and containing the admixture of aluminum chloride and residues of highmolecular hydrocarbons is offered instead of traditional water-alkaline purification, creating the ecological problems and losses of valuable components.

2. The scheme regeneration of adsorbents from adsorbed admixtures allowing to use its repeteadly in adsorption process.

\section{References}

1. Lipovich V.Q., Polubentseva M.F. Alkylation of aromatic hydrocarbons. M. Chemistry, 1985. 281 p.

2. Porutski Q.V. Biochemical purification of waste wates of organic production, M. Chemistry, 1975. $253 \mathrm{p}$.

3. Muqanlinski F.F., Sadikhov F.M., Shakhverdiyeva F.M., Isayeva N.Y. "Purification by solid sorbents" // Scientific notes. ASOA. № 3, 1994.

4. Shakhverdiyeva F.M., Sadikhov F.M., Salimova N.A. "Ecological technologies": purification of alkylate by natural reolites // Journal "Engineering ecology". № 2, 2006. Issue "Engineering ecology". Moscow. Russian Federation.

5. Keltsev N.V. "Base of adsorption technique" second issue. M. "Chemistry", 1984. P. 592. 